\title{
Changes in breaded chicken and oil degradation during discontinuous frying with cottonseed oil
}

\author{
Alterações em frango empanado e degradação do óleo durante a fritura descontínua
} em óleo de algodão

\section{Cibele Cristina OSAWA ${ }^{1}$, Lireny Aparecida Guaraldo GONÇALVES ${ }^{1 \star}$}

\begin{abstract}
Discontinuous frying of breaded chicken in cottonseed oil was evaluated. Three $400 \mathrm{~g}$ batches of foodstuff were fried daily in a $28 \mathrm{~L}$ fryer at $182^{\circ} \mathrm{C}$ for 4.5 minutes for 7-8 days, and the experiment was repeated three times. The total polar compounds in the oil were determined by the conventional method. Changes in the oil were determined by the quick tests Testo 265, Viscofrit and Fri-check based on physical constants, and the results were compared with those of total polar compounds obtained by the conventional method. The free fatty acids, conjugated dienes, Lovibond color, oxidative stability, fatty acid composition, and polymeric compounds were also determined. During frying, the oil samples presented 6.0-39.2\% total polar compounds, $0.0-12.9 \%$ polymerized triacylglycerols, $1.3-14.5 \%$ oxidized triacylglycerols, $2.8-11.0 \%$ diacylglycerols, and 1.6-2.6\% fatty acids and unsaponifiable polar compounds. The breaded chicken samples lost moisture, absorbed oil up to approximately $6 \%$, and there were small changes in the fatty acid composition and low formation of trans-isomers. The best method for monitoring and discarding the oil was that used for the determination of total polar compounds.
\end{abstract}

Keywords: frying; fried foods; cottonseed oil.

\section{Resumo}

Neste trabalho, foi avaliada a fritura descontínua de frango empanado em óleo de algodão. Três bateladas de $400 \mathrm{~g}$ de alimentos foram fritas diariamente em uma fritadeira de $28 \mathrm{~L}$ a $182^{\circ} \mathrm{C}$ por 4,5 minutos durante $7-8$ dias. O experimento foi executado três vezes. Foram realizadas determinações de compostos polares totais no óleo pelo método convencional. As alterações do óleo, baseadas em constantes físicas, foram determinadas por meio dos testes rápidos Testo 265, Viscofrit e Fri-check e seus resultados foram comparados com os resultados de compostos polares totais obtidos pelo método convencional. Foram determinados, também, ácidos graxos livres, dienos conjugados, cor Lovibond, estabilidade oxidativa, composição em ácidos graxos e compostos poliméricos. Durante a fritura, as amostras de óleo apresentaram 6,0-39,2\% de compostos polares, $0,0-12,9 \%$ de triglicerídios polimerizados, 1,3-14,5\% de triglicerídios oxidados, 2,8-11,0\% de diglicerídios e 1,6-2,6\% de ácidos graxos e polares insaponificáveis. Em relação às amostras de frango empanado, estas perderam umidade, absorveram óleo até aproximadamente $6 \%$ e houve pequena alteração na composição em ácidos graxos ou formação de isômeros trans. O melhor método de monitoramento e descarte de óleo foi o de compostos polares totais.

Palavras-chave: frituras; alimentos fritos; óleo de algodão.

\section{Introduction}

Deep-fat frying is a very important operation since it is a rapid preparation process and offers unique odor and taste characteristics to the products. In this process, a complex series of chemical reactions and alterations take place producing numerous decomposition compounds (FRITSCH, 1981).

During the frying process, the oil or fat is posed to high temperatures in the range from 162 to $196{ }^{\circ} \mathrm{C}$ in the presence of air and water. Under such conditions, a series of complex simultaneous reactions occur, such as thermoxidation, polymerization, and hydrolysis, resulting in loss of quality of the frying oil and fried food (DOBARGANES; MÁRQUEZRUIZ, 1998).

The rate of formation of decomposition products varies with the food to be fried, type of oil used for frying, fryer design (relationship between the fryer surface and the volume of oil), and the nature of the operating conditions (STEVENSON; VAISEY-GENSER; ESKIN, 1984; CHOE; MIN, 2007; MACHADO et al., 2007; MACHADO; GARCÍA; ABRANTES, 2008).

Discontinuous frying, adopted in food services, is characterized by heating and cooling cycles. Depending on the menu and the local food patterns, the fryer operates with a total capacity of a few hours per day, working intermittently for a few hours and remaining unused for the remaining time. This intermittent operation is one of the main reasons for the greater oil degradation than that occurring in continuous frying. During the period of low production, the oil is subjected to oxidative and thermal stress (BANKS, 1996).

\footnotetext{
Received 6/5/2011

Accepted 25/5/2012 (005271)

1 Laboratory of Oils and Fats, Department of Food Technology, School of Food Engineering, University of Campinas - UNICAMP, CP 6091, CEP 13081-970, Campinas, SP, Brazil,e-mail: lireny@fea.unicamp.br

${ }^{*}$ Corresponding author
}

DOI: http://dx.doi.org/10.1590/S0101-20612012005000098 
When the oil is cooled, the oxygen solubility increases accelerating the oxidation reactions and peroxide production. When the oil is reheated again, the peroxides, which are unstable compounds at high temperatures, originate decomposition products (BANKS, 1996; PAUL; MITTAL, 1997).

In the deep-fat frying process, the oil used has the function of stabilizing the fried product, and it confers important and desirable sensory characteristics to the food. The stability of fried products is related to the degree of unsaturation of the fatty acids in the frying oil. Compared with stearic acid (18:0), the relative rate of oxidation is 100 for oleic acid (18:1), 1.200 for linoleic acid (18:2), and 2.500 for linolenic acid (18:3) (BELITZ; GROSCH, 1999). In general, the most stable oils for frying have low linolenic acid contents $(<3 \%)$, more than $50 \%$ of oleic acid, and linoleic acid below 50\% (WARNER; FEHR, 2008).

Therefore the ideal frying medium is that with the lowest possible linolenic acid content, less than 2\% (FIRESTONE; STIER; BLUMENTHAL, 1991; AGÊNCIA..., 2004). One option is cottonseed oil due to: its commercial availability; the fact that it does not confer disagreeable odors and tastes to fried foods; its linolenic acid content, which is below $1 \%$; and its minimal trans-fat content in the recommended daily intake portions (O'BRIEN et al., 2005).

There is a great deficiency of quick tests that are simple and direct in the prediction of oil degradation (INNAWONG; MALLIKARJUNAN; MARCY, 2004). Of those available for the evaluation of frying oil, the most famous are based on changes in the dielectric constant, which is related to the level of total polar compounds in the frying oil. Nowadays, the Belgian FriCheck $^{\circledR}$ (FRAIS, 2009) and the German Testo 265 (TESTO, 2009) are the quick measurement options available to determine total polar compounds. Viscofrit ${ }^{\circledR}$ produced by the Spanish laboratory Seguridad Alimentaria, is another option of a quick test that evaluates whether the total polar compound content has surpassed 25\% based on the oil viscosity (VISCOFRIT, 2006). According to international laws, frying oil which surpasses $25 \%$ of total polar compounds must be discarded (PAUL; MITTAL, 1997). The Fri-Check ${ }^{\circledR}$ consists of a quick test system which determines the thermoxidation and hydrolytic degradation of oils and fats. The main advantage of this equipment is the significant reduction of analysis time, 5 minutes only. The measurements are based simultaneously on three physical parameters: density, viscosity, and surface stress. The results are expressed in Fri-Check ${ }^{\circledR}$ units (U) or total polar compound equivalents (\%PM) (GERTZ, 2000).

Testo 265 is a portable equipment for measuring total polar compound (TPC), based on the measurement of the dielectric constant. The temperature range is between 40 and $210{ }^{\circ} \mathrm{C}$, and the reading was performed at 25 to 30 seconds with the equipment in contact with the frying oil (TESTO, 2009).

Viscofrit ${ }^{\circledR}$ is a laboratory method for the monitoring of frying oil and fat which has been recommended by the Spanish government since 1989 and has been used by the La Grasa Institute in Sevilla (Spain). It is economical, robust, reliable, easy to handle device and it can be used for an unlimited period of time without generating tainted substances. It consists of a small cone containing a standard volume of oil connected to a thermometer with time and temperature scales. The Viscofrit ${ }^{\circledR}$ response is based on an increase in viscosity. If the time the oil takes to flow is greater than the time indicated in the thermometer, it means that the oil has a total polar compound content over $25 \%$ and should be discarded. Since the oil viscosity is associated with the fatty acid composition, there are two different types of calibrated thermometers for each kind of oil composition: the oleic and the linoleic oil types (VISCOFRIT, 2006). Viscofrit has some limitations with high melting point samples (MARMESAT et al., 2007) since it requires samples in a totally liquid state and with operational temperatures of 20-30 ${ }^{\circ} \mathrm{C}$ (VISCOFRIT, 2006). This study aimed to evaluate the quality of the cottonseed oil used in the discontinuous frying of breaded chicken products under conditions of stress, using quick tests and conventional methods, and to determine the alterations occurring in the fried foods, such as moisture content, oil incorporation, fatty acid composition, and the formation of trans isomers.

\section{Material and methods}

Three cycles of raw frozen breaded skinless and deboned chicken breast (Braslo, Brazil) were fried in cottonseed oil (Cargill, Brazil) in a FryMaster electric fryer (donated by McDonald's, Brazil) with 2 tanks, each with dimensions of $34.5 \mathrm{~cm} \times 51.0 \mathrm{~cm}$. Only one tank was used adding $28 \mathrm{~L}$ of oil, so that the initial relationship between the surface of the fryer and the volume of oil $(\mathrm{S} / \mathrm{V})$ was $0.06 \mathrm{~cm}^{-1}$. During the frying process, there was no oil replacement and the oil was not filtered.

The oil was initially heated for 3 hours before carrying out the first frying of the day. After a further 3 hours, the second frying of the day was carried out, and, 2 hours later, the last frying was carried out. The fryer was then turned off.

The frying time was 4.5 minutes at a temperature of $182^{\circ} \mathrm{C}$ for each batch of approximately $400 \mathrm{~g}$ of raw frozen breaded chicken, and approximately $1,200 \mathrm{~g}$ of food was fried per day.

After frying, approximately $200 \mathrm{~g}$ of fried foods from each fried batch were conditioned inside polyethylene films and kept frozen at $-18{ }^{\circ} \mathrm{C}$ for analysis. The remaining samples were submitted to sensory analysis by untrained tasters in order to detect undesirable sensory characteristics in the product.

Some samples destined to physicochemical analyses were defrosted and then ground in a multiprocessor removing the necessary amount of ground sample for each analysis. Before starting the experiments, approximately $100 \mathrm{~mL}$ of oil samples were collected for analysis. The samples collected were placed in amber vials and kept frozen until analysis for determination of the degradation in the frying oil, using the following quick tests: Testo 265 (Testo do Brasil, Brazil), Viscofrit (Laboratório de Seguridad Alimentaria, Spain) and Fri-Check (Frais Imp. E Exp. Ltda, Brazil). All tests were carried out in triplicate. The information obtained using these tests determined whether the oil should be discarded, that is, if the total polar compound content is greater than 25. According to international law, frying oils with more than $25 \%$ of total polar compounds must be discarded (PAUL; MITTAL, 1997). 
Three repetitions of the frying process were carried out (cycles) under the same experimental conditions, using the same type of fried food and the same type of frying oil. The end of each cycle was defined when the frying oil was condemned by at least two quick tests, since the conventional method of determining the total polar compounds using an open column did not provide the results "in situ" within a few minutes of analysis. For cycles 1 and 2 , the experiment was terminated after 9 days of using, and for cycle 3 , after 8 days of use.

\subsection{Fried food analyses}

Moisture: carried out based on the AOAC method (HORWITZ, 1980) with modifications. At least $50 \mathrm{~g}$ of samples were ground in a food processor and homogenized. Petri plates were codified and placed in an oven at $105^{\circ} \mathrm{C}$ for a minimum of 1 hour, followed by cooling in a desiccator. The Petri plates were weighed on an analytical balance and $10 \mathrm{~g}$ of ground, homogenized sample were weighed into the petri plate. The plates containing the samples were heated in an oven at $105^{\circ} \mathrm{C}$ for 1 hour, cooled in a desiccator, and weighed. They were then placed back in the oven for a further 1 hour at $105^{\circ} \mathrm{C}$, cooled, and weighed; this process was repeated until constant weight.

Oil Content: determined by acid hydrolysis according to the procedures adopted by Osawa (2005). For protein foods with or without significant amounts of carbohydrates, acid hydrolysis is required in order to free the lipids covalently bonded to the proteins and carbohydrates (SHAHIDI; WANASUNDARA, 1998).

Fatty Acid Composition: determined by stearification according to the Hartman and Lago method (1973). The methyl esters obtained by stearification were injected into the Agilent Gas-phase Chromatography 6850 Series GC System, using a $60 \mathrm{~m}$ Agilent DB-23 capillary column (50\% cyanopropyl - methylpolysiloxane), with an internal diameter of $0.25 \mathrm{~mm}$ and $0.25 \mu \mathrm{m}$ stationary phase. The following temperatures were used: detector at $280^{\circ} \mathrm{C}$, injector at $250^{\circ} \mathrm{C}$, oven at $195{ }^{\circ} \mathrm{C}$ for 20 minutes, $195-215^{\circ} \mathrm{C}\left(5^{\circ} \mathrm{C} / \mathrm{min}\right)$, and $215^{\circ} \mathrm{C}$ for 16 minutes. Helium flow was of $1.00 \mathrm{~mL} / \mathrm{min}$, rate Split of 1:50, and linear speed of $24 \mathrm{~cm} /$ seconds. The volume injected was $1.0 \mu \mathrm{L}$ (automatic injector). The fatty acids were identified by comparison with a mixture of methyl ester standards (C4-C24).

All determinations were carried out in duplicate. The food samples analyzed were those from the second day of frying (designated as Day 1) and from the last day of frying (designated as Day 7 for cycle 1 and as Day 6 for cycles 2 and 3), considering that the first day of frying was designated as Day 0, and on Day 0 , the oil sample was the fresh oil.

\subsection{Frying oils analyses}

Lovibond color: Method Cc 13e-92 (AMERICAN..., 2004), using the Lovibond Tintometer Model E manual and 5 1/4", 1" or 0.5 " cuvettes, in quadruplicate.

Free Fatty Acids: determined according to the method adopted by Osawa, Gonçalves and Ragazzi (2006), in duplicate, using $1.5 \mathrm{~g}$ samples for fresh oils, $1.0 \mathrm{~g}$ samples for used oils and the TitroLine easy titrator (SCHOTT, Germany) adjusted to stop titrating at $\mathrm{pH}=8.8$.

Conjugated Dienes: spectrophotometric Method Ti 1a-64 (AMERICAN..., 2004) in duplicate.

Total Polar Compounds and fractions (dimerized and polymerized triacylglycerols, oxidized triacylglycerols, diacylglycerols, monoacylglycerols and free fatty acids): determined according to the method developed by Dobarganes, Velasco and Dieffenbacher (2000), in duplicate. The method is based on the elution of non-polar and polar fractions on a silica column, with eluents of different polarity: petroleum ether: diethyl ether 90:10 (v/v), and ethyl ether. The solvents were recovered and the percentage of apolar and polar fractions, respectively, were determined by the difference in weight. The effectiveness of the separation was evaluated by thin-layer chromatography, applying the polar and apolar factions separately and comparing it with the TLC of a refined vegetable oil, which is a sample with both polar and apolar fractions. The polar fraction was dissolved in tetrahydrofuran at a concentration of 0.01 g.mL $\mathrm{m}^{-1}$ for quantification of the dimerized and polymerized triacylglycerols, oxidized triacylglycerols, diacylglycerols, monoacylglycerols, and free fatty acids. These compounds were separated from the polar fraction by liquid phase chromatography, using a Perkin Elmer chromatograph with a Waters 510 pump and Rheodyne 7725i injector with a $20 \mu \mathrm{L}$ sampler (Waters Associates, USA). Two gel permeation columns (copolymer styrene divinylbenzene), one of $500 \AA$ and the other $100 \AA$, were connected in series. Each column had an i.d. of $25 \times 0.77 \mathrm{~cm}$, and the mobile phase was chromatographic grade tetrahydrofuran at a flow rate of $1.0 \mathrm{~mL}$. The detector used was a Merck L-7490 refractive index detector (Merck, Germany) together with a Hewlett-Packard HP 3390A integrator (Hewlett-Packard, USA).

Fatty Acid Composition: determined using the same methodology adopted for the oil extracted from the fried foods, in duplicate.

Oxidative Stability: Cd 12b-92 (AMERICAN..., 2004) method, using the Oxidative Stability Instrument (OSI) (Omnion Archer - Daniels Midland Company), $5 \mathrm{~g}$ of sample, temperature of $110^{\circ} \mathrm{C}$, and air flow of $10 \mathrm{~L} /$ hour, in duplicate.

Rapid Tests: Viscofrit, Fri-Check ${ }^{\circledR}$ and Testo 265, according to the manufacturer's instructions, in triplicate.

\section{Results and discussion}

\subsection{Alterations in the foods during frying}

\section{Moisture and oil absorption}

The moisture content of the frozen breaded skinless chicken was $64.7 \pm 0.4 \%$, and the lipid content was $1.6 \pm 0.2 \%$ (Table 1 ). With the frying process, there was a reduction in moisture content and incorporation of oil into the food, reaching average levels of $57 \%$ moisture and $6 \%$ total lipids. 
The differences in moisture and oil content between the first and last days of frying were almost imperceptible for cycles 1 and 2 (Table 1). The variation in moisture content between the first and last days of frying was from $57.6 \pm 0.8 \%$ to $57.3 \pm 0.1 \%$ and from $57.3 \pm 0.4 \%$ to $57.5 \pm 0.2 \%$ for cycles 1 and 2 , respectively. As for the oil content, the variation was from $7.0 \pm 0.1 \%$ to $7.3 \pm 0.6 \%$ (cycle 1 ) and from $5.8 \pm 0.9 \%$ to $5.4 \pm 0.0 \%$ (cycle 2 ).

However, a significant difference in moisture content was observed for cycle 3 (from $55.1 \pm 0.2 \%$ to $49.1 \pm 0.9 \%$ ) and in oil absorption (from $6.7 \pm 0.1 \%$ to $8.6 \pm 1.0 \%$ ) when comparing the first and the last day of frying (Table 1).

Oil absorption may be described by two mechanisms: 1) continuous oil absorption as a replacement for the water evaporated during frying; and 2) an absorption process, occurring mainly at the end of frying (SAGUY; DANA, 2003).

The increase in oil absorption during frying when using oil close to its expiration date may be explained by the surfactant theory. As the oil deteriorates, more surfactants are formed and there is an increase in contact time between the food and the oil. As a result, the quantity of oil absorbed by the food and the rate of heat transfer increases, generating a decrease in moisture evaporation and darkening of the surface, depending on the temperature gradient (PAUL; MITTAL, 1997).

\section{Fatty acid composition and trans isomers}

In order to evaluate the fatty acid composition of fried foods, one must first analyze the alterations in the fatty acid composition in the fatty acid fraction of the oils used during frying.

According to Table 2, the fresh cottonseed oil presented a fatty acid composition in agreement with that of the Codex Alimentarius (CODEX..., 2003) for cottonseed oil: 21.4 to $26.4 \%$ of palmitic acid (16:0); 2.1 to $3.3 \%$ of stearic acid (18:0); 14.7 to 21.7 of oleic acid (18:1); 46.7 to $58.2 \%$ of linoleic acid (18:2), and 0.05 to $0.4 \%$ of linolenic acid (18:3).

Comparing the fresh oil with samples of the used oil on the last day of frying for each cycle, a slight decrease in the linoleic acid content (18:2) could be observed, more notably for cycle 2 (Table 2 ). In cycle 1 , the $18: 2$ ratio decreased to $52.2 \%$, while in cycle 2 it decreased to $48.3 \%$ (Table 2). The apparent increase from $55.0 \%$ to $55.9 \%$ in cycle 3 (Table 2) may be attributed to

Table 1. Moisture and oil contents of the foods fried in cottonseed oil.

\begin{tabular}{|c|c|c|c|c|}
\hline \multicolumn{2}{|c|}{ Samples } & Days of use & $\begin{array}{l}\text { Moisture } \\
\left(\text { g. } 100 \mathrm{~g}^{-1}\right)\end{array}$ & $\begin{array}{c}\text { Oil content } \\
\left(\mathrm{g} .100 \mathrm{~g}^{-1}\right)\end{array}$ \\
\hline \multicolumn{2}{|c|}{ Raw breaded chicken } & 0 & $64.7 \pm 0.4$ & $1.6 \pm 0.2$ \\
\hline \multirow{6}{*}{$\begin{array}{l}\text { Fried } \\
\text { chicken }\end{array}$} & Cycle 1 & 1 & $57.6 \pm 0.8$ & $7.0 \pm 0.1$ \\
\hline & & $7^{\star}$ & $57.3 \pm 0.1$ & $7.3 \pm 0.6$ \\
\hline & Cycle 2 & 1 & $57.3 \pm 0.4$ & $5.8 \pm 0.9$ \\
\hline & & $6^{*}$ & $57.5 \pm 0.2$ & $5.4 \pm 0.0$ \\
\hline & Cycle 3 & 1 & $55.1 \pm 0.2$ & $6.7 \pm 0.1$ \\
\hline & & $6^{*}$ & $49.1 \pm 0.9$ & $8.6 \pm 1.0$ \\
\hline
\end{tabular}

*Samples corresponding to the last day of frying food. experimental errors, stemming from the integration area of the chromatographic peak.

The decrease in unsaturated acids is attributed to oxidative reactions occurring during frying, with the formation of total polar compounds. When computing the percent areas of the chromatographic peaks of other fatty acids present in the oils, apparent increases in the percentages of saturated fatty acids and of oleic acid may occur. These apparent increases in percentage are related to the computing tools used to quantify the fatty acids and do not have scientific significance in fried foods. However, comments on the increase in saturated fatty acids or oleic acid are not justified.

The alteration observed in the saturated fatty acids corroborates those found by Machado, García and Abrantes (2008), who explained this experimental mistake in computing the fatty acid composition without considering the losses resulting from the formation of decomposition frying products, which was most perceptible in fried foods. When observing the alterations in the fatty acid composition of the fried foods with time, a significant decrease in linoleic acid (18:2) was noted when comparing the samples from the $2^{\text {nd }}$ day of frying (Day 1) with those from the last day of frying (Day 7 for cycle 1 and Day 6 for cycles 2 and 3). This variation was from $43.8 \%$ to $25.9 \%$ for cycle 1 ; from $24.4 \%$ to $8.3 \%$ for cycle 2 , and from 25.1 to $18.3 \%$ for cycle 3 (Table 3 ). This means that the decrease in polyunsaturated fats occurred proportionally to the increase in the total polar compounds of the oils that increased with the time of frying (Tables 2 and 4).

As for the trans fatty acid contents, it is known that frying favors the formation of trans isomers and that ingestion of these fatty acids is detrimental to health (SUNDRAM, 1997). Since the consumption of trans fats is not recommended, independent of the percentage present in the food portion, the amount of trans fats in terms of the percentage of daily values is not mentioned on the nutritional labeling of packaged foods (BRASIL, 2003b; FOOD..., 2009).

The formation of trans isomers in the cottonseed oil during frying was more evident in cycle 2, although at low levels, implying that the oil deteriorated at a faster rate in this cycle than in the others (Table 2). In addition, the total polar compound

Table 2. Fatty acid composition in the fatty acid fraction of the cottonseed oil used to fry the breaded chicken ( $\%$ area).

\begin{tabular}{|c|c|c|c|c|}
\hline \multirow{2}{*}{$\begin{array}{l}\text { Fatty } \\
\text { acid }\end{array}$} & \multirow{2}{*}{$\begin{array}{c}\text { Day 0 } \\
\text { (Fresh oil) }\end{array}$} & Cycle 1 & Cycle 2 & Cycle 3 \\
\hline & & $\begin{array}{c}\text { Day } 9 \\
\text { (Discard) }\end{array}$ & $\begin{array}{c}\text { Day } 9 \\
\text { (Discard) }\end{array}$ & $\begin{array}{c}\text { Day } 8 \\
\text { (Discard) }\end{array}$ \\
\hline $8: 0$ & - & 0.1 & 0.3 & 0.3 \\
\hline $12: 0$ & 0.2 & 0.1 & 0.1 & 0.3 \\
\hline $14: 0$ & 0.8 & 0.8 & 0.9 & 1.1 \\
\hline $16: 0$ & 22.8 & 24.5 & 25.6 & 28.7 \\
\hline $16: 1$ & 0.5 & 0.5 & 0.5 & 0.6 \\
\hline $18: 0$ & 2.6 & 2.7 & 1.7 & 3.3 \\
\hline $18: 1$ & 16.8 & 17.3 & 19.5 & 20.1 \\
\hline $18: 2$ & 55.0 & 52.2 & 48.3 & 55.9 \\
\hline $18: 3$ & 0.2 & 0.1 & 0.1 & 0.2 \\
\hline Trans & 0.7 & 0.9 & 2.3 & 0.5 \\
\hline
\end{tabular}


content was greater in the last sample of cycle $2(39.2 \pm 1.0 \%)$, when compared with the last samples of cycles 1 and 3 (days 7 and 6 , respectively), with $20.2 \pm 0.9 \%$ and $35.2 \pm 0.3 \%$ (Table 4 ), respectively. Since there are changes in the lipids between the food and the frying medium due to the incorporation of lipids originating from the frying oil, it is understandable that on the last day of frying the fried food from cycle 2 presented the highest content of trans isomers (2.5\%) if compared to the other fried foods (0.4-1.2\% of trans isomers).

However, the samples of used frying oil and the fried food obtained in this study were considered free of trans fatty acids in the recommended daily portion for consumption (Tables 2 and 3 ), according to current legislation (BRASIL, 2003a; b; FOOD..., 2009 ), since $2.5 \%$ of trans isomers in a lipid fraction of a fried food containing $5.4 \pm 0.0 \%$ of oil represents less than $0.2 \mathrm{~g}$ of trans isomers in the portion of $130 \mathrm{~g}$ of the fried breaded chicken (BRASIL, 2003a), which may be declared as zero grams transfat in the nutrition facts label. For the trans fat content of the frying oils, the same argument is valid for all samples, except for the cycle 2 sample, whose trans-fat content is around 0.3 . However, for this sample, its total polar compounds surpassed $25 \%$, indicating that the oil was not appropriated to be used in deep-fat frying.

Table 3. Fatty acid composition in the fatty acid fraction of the fried foods (\% area).

\begin{tabular}{crrrrrr}
\hline \multirow{2}{*}{ Fatty acid } & \multicolumn{2}{c}{ Cycle 1 } & \multicolumn{2}{c}{ Cycle 2 } & \multicolumn{2}{c}{ Cycle 3 } \\
\cline { 2 - 7 } & Day 1 & Day 7* & Day 1 & Day 6* & Day 1 & Day 6* \\
\hline $12: 0$ & 0.2 & 0.1 & 0.2 & 0.7 & 0.4 & 0.8 \\
$14: 0$ & 1.1 & 0.6 & 1.4 & 1.9 & 1.1 & 1.8 \\
$16: 0$ & 23.9 & 22.1 & 39.0 & 45.4 & 33.5 & 41.9 \\
$16: 1$ & 0.9 & 0.7 & 0.8 & 0.8 & 1.0 & 1.1 \\
$18: 0$ & 4.2 & 3.9 & 6.2 & 9.5 & 5.9 & 6.1 \\
$18: 1$ & 23.7 & 31.5 & 23.6 & 28.5 & 30.0 & 27.3 \\
$18: 2$ & 43.8 & 25.9 & 24.4 & 8.3 & 25.1 & 18.3 \\
$18: 3$ & 0.3 & 0.7 & 0.4 & 0.7 & 0.6 & 0.3 \\
$20: 0$ & 0.3 & 0.3 & 0.5 & 0.6 & 0.6 & 0.5 \\
$20: 1$ & 0.1 & 0.1 & 0.8 & 0.2 & 0.1 & 0.3 \\
$22: 0$ & 0.2 & 0.2 & 1.0 & 0.5 & 0.4 & 0.4 \\
$22: 1$ & 0.0 & 0.4 & 0.8 & - & - & - \\
$24: 0$ & 0.1 & 0.1 & 0.2 & 0.2 & 0.2 & 0.3 \\
Trans & 0.9 & 0.4 & 1.2 & 2.5 & 0.9 & 0.4 \\
\hline *Samples corresponding to the last day of frying. & & &
\end{tabular}

Table 4. Total polar compound content (\%) of the cottonseed oil used to fry the breaded chicken.

\begin{tabular}{cccc}
\hline Days of use & Cycle 1 & Cycle 2 & Cycle 3 \\
\hline 0 (Fresh oil) & $8.1 \pm 0.4$ & $10.7 \pm 1.0$ & $6.0 \pm 1.1$ \\
3 & $24.4 \pm 1.7$ & $22.9 \pm 0.4$ & $23.7 \pm 1.4$ \\
5 & $14.5 \pm 0.3$ & $28.2 \pm 0.2$ & $28.7 \pm 0.5$ \\
7 & $17.8 \pm 2.3$ & $33.8 \pm 0.2$ & a \\
8 & a & a & $35.2 \pm 0.3$ \\
9 (Discard) & $20.2 \pm 0.9$ & $39.2 \pm 1.0$ & b \\
\hline
\end{tabular}

${ }^{a}$ not determined. bthe oil in this cycle was used for one day less than in the other cycles. Therefore, the discard for this cycle corresponds to Day 8 of use.
These results confirm the findings of Saguy and Dana (2003), who argued that the concentration of trans isomers formed in frying oils is minimal when considering a recommended $13 \mathrm{~mL}$-daily intake of vegetable edible oils (BRASIL, 2003a), as long as hydrogenated fats are not used. Using canola oil, Aladedunye and Przybylski (2009) did not observe the formation of trans fatty acids at typical frying temperatures although foods cannot be declared free of trans-fats when fried at temperatures above $195^{\circ} \mathrm{C}$.

\subsection{Alterations in the oils during frying}

\section{Total polar compounds}

Observing the values obtained for total polar compounds in the oils used in the various frying cycles (Table 4), it can be seen that frying is not a repetitive process when using the same type of oil to fry the same type of food. On the $9^{\text {th }}$ day of the first cycle of frying chicken in cottonseed oil, the polar content had still not reached the stipulated value of $25 \%$. However, in the $2^{\text {nd }}$ and $3^{\text {rd }}$ cycles the oil was condemned between the $3^{\text {rd }}$ and $5^{\text {th }}$ days of frying.

\section{Oxidative stability}

Similarly, since the values for total polar compounds in the oils on the last day of use were closer to each other in cycles 2 and 3 , and very different from the value for total polar compounds found in the sample of oil on the last day of use in cycle 1. Similar findings may be observed with respect to the induction periods (Table 5). The discarded oil from cycle 1 presented a period of induction of $3.4 \pm 0.1$ hours, whereas the induction periods for cycles 2 and 3 were somewhat close to each other with values of $1.6 \pm 0.2$ hours and $1.5 \pm 0.4$ hours, respectively.

What can be observed from the results for oxidative stability and total polar compounds is that the oxidative stability has an inverse relationship with the total polar compounds, decreasing with frying time or with oil degradation. For cycle 1, the unused oil presented $8.1 \pm 0.4 \%$ of total polar compounds and $8.1 \pm 0.4$ hours of oxidative stability; whereas the discharged sample presented $20.2 \pm 0.9 \%$ of total polar compounds and $3.4 \pm 0.1$ hours of oxidative stability. Moreover, the discharged sample from cycle $1(20.2 \pm 0.9 \%$ of TPC) presented the highest value for oxidative stability (3.4 \pm 0.1 hours) amongst the discharged samples; the other two showed $39.2 \pm 1.0 \%$ and $35.2 \pm 0.3 \%$ for total polar compounds and $1.6 \pm 0.2$ hours and $1.5 \pm 0.4$ hours for oxidative stability, for cycles 2 and 3 , respectively (Table 5). The values for the induction periods of the fresh oils used in the 3 cycles were close to each other (Table 5) in the time period of 5.5 hours ( $5.6 \pm 0.3$ hours; $5.2 \pm 0.2$ hours

Table 5. Oxidative stability of the cottonseed oil used to fry breaded chicken in hours ${ }^{*}$ at $110^{\circ} \mathrm{C}$.

\begin{tabular}{cccc}
\hline Days of use & Cycle 1 & Cycle 2 & Cycle 3 \\
\hline Fresh oil & $5.6 \pm 0.3$ & $5.2 \pm 0.2$ & $6.1 \pm 0.2$ \\
Discard & $3.4 \pm 0.1$ & $1.6 \pm 0.2$ & $1.5 \pm 0.4$ \\
\hline
\end{tabular}

$\star 5 \mathrm{~g}$ of sample with an air flow of $10 \mathrm{~L} / \mathrm{h}$. 
and $6.1 \pm 0.2$, respectively, for cycles 1,2 , and 3 ). With respect to the total polar compounds in the fresh oils (Table 4), although not so close to each other, it is possible that the initial quality of the cottonseed oil had no influence on the lack of repeatability of the frying process. Besides, there are other factors that should be analyzed. In the three frying cycles, the foods used and the cottonseed oil were from the same batch, the frying time and temperature were the same, the time interval between one frying and another was the same, and the same fryer was used. This was done because the rate of formation of decomposition products in frying oils varies with the food fried, the oil used, the choice of fryer, the nature of the operating conditions (time and temperature), the oil level replenishment, quality of the oil and the presence of antioxidants (STEVENSON; VAISEYGENSER; ESKIN, 1984; CHOE; MIN, 2007; MACHADO et al., 2007; MACHADO; GARCÍA; ABRANTES, 2008).

The fryer used in the experiments was sufficiently potent to recover in a few minutes (around 2 minutes) after the lowering of the temperature of the oil by the addition of frozen food; although there may be minimal temperature variations throughout the process. A fryer with a large volume was chosen so that the daily lowering of the oil level, caused by sample taking for analysis and the incorporation of oil into the fried foods, would not significantly affect the relationship between the fryer surface and oil volume. This ratio should preferably be small enough to reduce oil oxidation (CHOE; MIN, 2007).

The use of different fryers may induce unequal heating and cooling periods, due to the sensor in each fryer and the use of varied initial temperatures, resulting in unequal temperatures in the oil during the various periods of the process (before and after addition of the food and before and after frying), for the same time of heating, causing different levels of alteration of the oil (MACHADO; GARCÍA; ABRANTES, 2008).
The lack of repeatability of the frying process may be explained by the following uncontrollable factors: differences in the time of cooling of the oil that was subject to the environmental conditions; the presence of residues of flour from the breading that detached from the food (a variable that was neither quantified nor controlled), the time of recovery of the temperature after addition of the food to the fryer, the absorption of oil by the foods, which altered the oil level and, minimally, the ratio between the surface of the fryer and the oil volume.

\section{Quick tests}

None of the quick tests used to determine when to discard the oil provided data with $100 \%$ precision (Table 6). The differences amongst the results obtained using the three quick tests compared to those of the official method can be attributed to the different principles of analysis of each one.

Among the quick tests used, Viscofrit can be considered the most reliable, with 1 error in 14 samples. It condemned sample 9 of cycle 1 although this sample only presented $21.2 \pm 0.9 \%$ total polar compounds (Table 6).

It can be seen in Table 6 that if only Testo 265 was taken into account without considering the conventional method, the moment the frying oil should be discarded would be before attaining $25 \%$ of total polar compounds for all cycles. The measurements made by Testo 265 are based on variations in the dielectric constant (TESTO, 2009), and hence the presence of water in the food influences the results, overestimating them, since water increases the dielectric constant (MARMESAT et al., 2007).

With respect to the Fri-check test, no uniform behavior could be predicted from its results, when compared to those obtained by the official method for the determination of the total polar compounds.

Table 6. Comparison of the results obtained by determining the total polar compounds with those obtained using the quick tests for the cottonseed oil used to fry the breaded chicken.

\begin{tabular}{|c|c|c|c|c|c|}
\hline \multicolumn{2}{|c|}{ Sample } & \multirow{2}{*}{$\begin{array}{l}\text { Official } \\
\text { method }^{\mathrm{a}}\end{array}$} & \multirow{2}{*}{ Testo $265^{\mathrm{a}}$} & \multirow{2}{*}{ Fri-check ${ }^{\mathrm{a}}$} & \multirow{2}{*}{ Viscofrit: pol. $>25 \% ?$} \\
\hline Frying cycle & Days of frying & & & & \\
\hline \multirow[t]{5}{*}{ Cycle 1} & 0 (Fresh) & $8.1 \pm 0.4$ & $14.2 \pm 0.3$ & $0.8 \pm 1.3$ & - \\
\hline & 3 & $24.4 \pm 1.7$ & $19.2 \pm 0.3$ & $2.5 \pm 0.2$ & No \\
\hline & 5 & $14.5 \pm 0.3$ & $22.2 \pm 0.3$ & $3.7 \pm 1.1$ & No \\
\hline & 7 & $17.8 \pm 2.3$ & $25.5 \pm 0.0$ & $7.2 \pm 0.8$ & No \\
\hline & 9 (Discard) & $20.2 \pm 0.9$ & $28.0 \pm 0.0$ & $11.4 \pm 1.7$ & Yes \\
\hline \multirow{3}{*}{ Cycle 2} & 5 & $28.2 \pm 0.2$ & $34.3 \pm 0.3$ & $17.8 \pm 1.5$ & Yes \\
\hline & 7 & $33.8 \pm 0.2$ & $42.0 \pm 0.9$ & $29.5 \pm 1.2$ & Yes \\
\hline & 9 (Discard) & $39.2 \pm 1.0$ & $41.7 \pm 0.3$ & $36.2 \pm 4.4$ & Yes \\
\hline \multirow[t]{2}{*}{ Cycle 3} & 0 & $6.0 \pm 1.1$ & $16.8 \pm 0.6$ & $1.5 \pm 1.3$ & - \\
\hline & 3 & $23.7 \pm 1.4$ & $28.0 \pm 0.0$ & $8.0 \pm 0.9$ & No \\
\hline
\end{tabular}

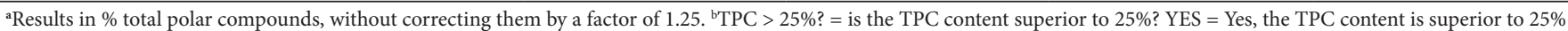
and the oil should be discarded. No $=$ No, the TPC content is inferior to $25 \%$ and the oil may be continuously used. 
Given the small number of samples, other studies are necessary to consider them as valid tools or otherwise. However, a tendency for Testo 265 to overestimate the results was observed by presenting false positive results, which would entail economic losses, since frying oil could be discarded unnecessarily before hitting the $25 \%$ total polar compound mark, a limit internationally established for the discarding of frying oils (PAUL; MITTAL, 1997).

The results obtained from the Viscofrit and Fri-check tests were more similar to those of the conventional method, despite the fact that the correction factor of 1.25 recommended by Osawa, Gonçalves and Grimaldi (2005) had not been applied to the Fri-check results. After applying the correction factor, the number of false positive or false negative results did not change.

Even though it was not possible to carry out correlation studies between the results obtained using the rapid tests and those obtained by conventional methods, Viscofrit was considered to be a reliable method for the evaluation of frying oils. The numbers of false positives and false negatives in one study involving 105 samples of frying oils of different origins were, respectively, $4.8 \%$ and $1.9 \%$, values low enough to be considered tolerable (MARMESAT et al., 2007).

\section{Polar fractions}

In addition to the increase in total polar compounds during frying, there was an increase in polymerized triacylglycerols (dimers and polymers), resulting from polymerization of the oil, from oxidized triacylglycerols, and from diacylglycerols, as shown in Table 7. Table 7 shows the amounts of polar fractions and polymeric compounds in terms of percentages of the oil sample, although the polymeric compounds were separated from the polar fraction of the samples.

Analyzing the limits for dimerized and polymerized triacylglycerols established by several countries, it was observed that they vary from $10 \%$ to $16 \%$ (PAUL; MITTAL, 1997; BASTIDA; SÁNCHEZ-MUNIZ, 2002). If the limit of $10 \%$ of dimerized and polymerized triacylglycerols were adopted, the same samples that were condemned for their contents of total polar compounds would be condemned by this criterion. This confirms that alterations in frying oils can be efficiently verified by a quantitative determination of the polymers (MACHADO; GARCÍA; ABRANTES, 2008).

\section{Free fatty acids}

The free fatty acid contents of the condemned oils were relatively low, $0.09 \%$ in oleic acid, and hence not reaching
2.5\% (PAUL; MITTAL, 1997). This indicates that in the case of discontinuous frying, the monitoring of free fatty acids is not a good parameter for evaluation, and that the alterations attributed to thermoxidation of the oil prevail over the hydrolytic alterations.

The hydrolysis of frying oil, common in continuous processes, causes an increase in free fatty acids, monoacylglycerols, diacylglycerols, and glycerols, whereas oxidation causes the formation of hydroperoxides as intermediary products, plus low molecular weight volatile compounds, such as aldehydes and ketones, carboxylic acids, and short chain alkanes and alkenes. Dimers, polymers, oxidized monomers, and oxidized fatty acids, such as hydroxyacids, ketoacids, and epoxyacids, are also formed in oxidized oil via reactions with radicals and Diels-Alder reactions during frying (FRITSCH, 1981; STEVENSON; VAISEY-GENSER; ESKIN, 1984; CHOE; MIN, 2007; MACHADO et al., 2008).

\section{Color}

The evolution of a red color during frying can be seen in Figure 1. In the method adopted to evaluate the color of the oils during frying, the intensity of yellow was considered less important than that of red. A proportion of 10 units of yellow for each unit of red may be adopted for oils, in which the red color is below 3.5, and more elevated levels of yellow are specified for darker oils (O'BRIEN et al., 2005). However, in the present study, complete freedom was given to the judges by not fixing the patterns of yellow.

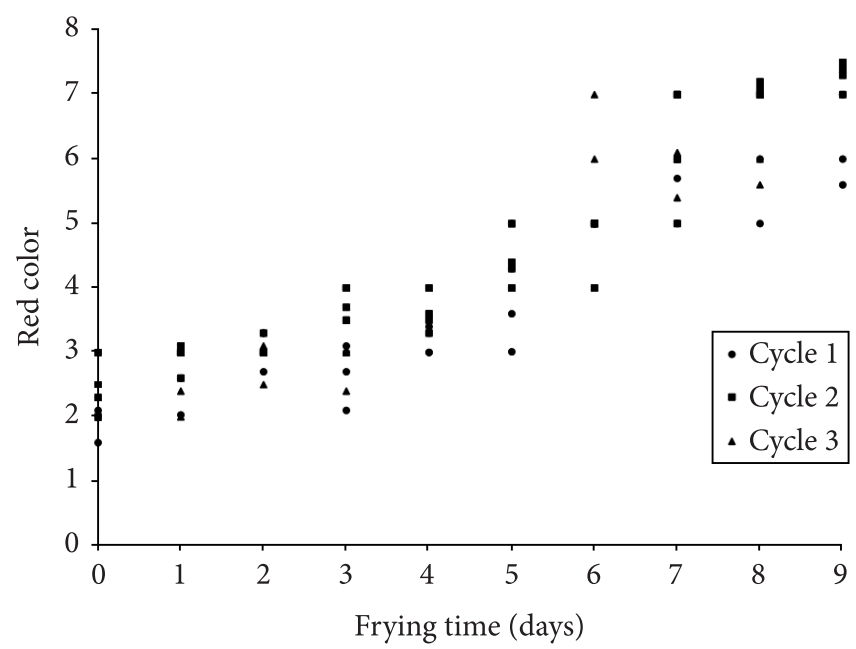

Figure 1. Evolution of the red color in the cottonseed oil during the frying of breaded chicken, using a $5 \frac{1 / 4}{4}$ " cuvette.

Table 7. Composition of the polar fraction in \% sample of the frying oils.

\begin{tabular}{|c|c|c|c|c|c|c|}
\hline & \multicolumn{2}{|c|}{ Cycle 1} & \multicolumn{2}{|c|}{ Cycle 2} & \multicolumn{2}{|c|}{ Cycle 3} \\
\hline & Day 0 (Fresh) & Day 9 (Discard) & Day 0 (Fresh) & Day 9 (Discard) & Day 0 (Fresh) & Day 8 (Discard) \\
\hline Total Polar fraction (\%) & $8.1 \pm 0.4$ & $20.2 \pm 0.9$ & $10.7 \pm 1.0$ & $39.2 \pm 1.0$ & $6.0 \pm 1.1$ & $35.2 \pm 0.3$ \\
\hline Polymerized TG (\%) & $0.0 \pm 0.0$ & $4.8 \pm 0.6$ & $0.4 \pm 0.1$ & $10.9 \pm 2.9$ & $0.4 \pm 0.1$ & $12.9 \pm 0.8$ \\
\hline Oxidized TG (\%) & $1.4 \pm 0.0$ & $7.1 \pm 0.3$ & $2.1 \pm 0.0$ & $14.5 \pm 0.8$ & $1.3 \pm 0.2$ & $11.1 \pm 0.2$ \\
\hline DG $(\%)$ & $4.3 \pm 0.0$ & $6.1 \pm 0.3$ & $5.8 \pm 0.0$ & $11.0 \pm 0.4$ & $2.8 \pm 0.1$ & $8.6 \pm 0.3$ \\
\hline FA + unsap. polar (\%) & $2.4 \pm 0.0$ & $2.2 \pm 0.6$ & $2.3 \pm 0.0$ & $2.8 \pm 0.4$ & $1.6 \pm 0.1$ & $2.6 \pm 0.6$ \\
\hline
\end{tabular}


The oil, initially showing approximately 2.0 units of red, showed $6.4 \pm 0.7 ; 7.3 \pm 0.2$ and $6.4 \pm 0.7$ units of red at the end of the frying cycles 1,2, and 3, respectively. For these samples, the yellow color was, respectively, $56 \pm 15 ; 45 \pm 6$ and $36 \pm 14$ units, and the initial samples presented approximately 20 units of yellow. The increase in red color was due to particles of breading flour that contaminated the frying oil, and since the oil was not filtered, they just remained there. With the high temperatures of the oil, the particles underwent caramelization, forming carbonized particles in suspension, which darkened the oil (PAUL; MITTAL, 1997). One should also take into consideration the formation of products from the Maillard reaction in the darkening of the oil (BELITZ; GROSCH, 1999), and also the contribution of polymers to the color of the frying oil (STEVENSON; VAISEY-GENSER; ESKIN, 1984).

Additionally, the increase in color could be related to conjugated double bonds formed during frying. Conjugated double bonds induce the absorption of greater quantities of blue, causing an increase in the orange and brown colors in the oil (LIMA; GONÇALVES, 1994).

\section{Conjugated dienes}

In the present study, the discarded frying oils showed smaller conjugated diene contents (all with $0.06 \%$ ) than that of the fresh oil $(0.82 \%)$, which is not in agreement with the literature (LIMA; GONÇALVES, 1994; HOUHOULA; OREOPOULOU; TZIA, 2002; GERDE et al., 2007). This can be explained by the fact that equilibrium was established between the rate of formation of conjugated dienes and the rate of formation of polymers involving the conjugated dienes, and hence the absorption at $232 \mathrm{~nm}$ did not show large variation during the course of frying (PAUL; MITTAL, 1997). Thus, the determination of conjugated dienes is not a precise parameter to predict the moment the frying oil should be discarded. The decrease in conjugated dienes can be explained by their degradation to form other secondary products (GERDE et al., 2007).

\section{Conclusions}

Since frying is a rather complex and irreproducible operation, the "in situ" monitoring of the oil used in frying is essential, in order to define the moment it should be discarded.

The measurement of the total polar compounds is the most indicated method to verify alterations in the oil during discontinuous frying. The polymerized triacylglycerol content was proven to be a good method for the quality control of frying oils although there is no agreement between researchers about it. However, such determinations are costly and time consuming, and thus, validated quick tests, which produce results while the oil is in use, are necessary.

This study indicated that the Testo 265 and Viscofrit tests are strong potential candidates to replace the determinations of total polar compounds by the conventional method.

Other determinations, such as those of color, fatty acid composition, oxidative stability, free fatty acid contents, and the conjugated dienes are important parameters for quality control, but they cannot be used to predict the right moment to discard the oil.

\section{Acknowledgements}

The authors are grateful to Cargill for donating the cottonseed oil; to Braslo for donating the food samples; to McDonald's for lending the fryer; to Mr. Antonio Castellón for technical support about the use of the Viscofrit test; to Mr. José Carlos Cazzoli (frais@sigmanet.com.br) of Frais Imp. and Exp. Ltda. for the loan of the Fri-Check; to Testo do Brasil for monitoring the analyses made with Testo 265 , and to CNPq for the doctoral research grant (Process: 140387/2005-6).

\section{References}

ALADEDUNYE, F. A.; PRZYBYLSKI, R. Degradation and nutritional quality changes of oil during frying. Journal of the American Oil Chemists' Society, v. 86, p. 149-156, 2009.

AGÊNCIA NACIONAL DE VIGILÂNCIA SANITÁRIA - ANVISA. Informe Técnico $\mathrm{n}^{\circ} 11$, de 5 de outubro de 2004. Óleos e Gorduras Utilizados em Frituras. Brasília, 2004. Available from: <http:// www.anvisa.gov.br/alimentos/informes/11_051004.htm>. Accessed in: 11 out. 2004.

AMERICAN OIL CHEMISTS' SOCIETY - AOCS. Official methods and recommended practices of the American Oil Chemists' Society. Champaign: American Oil Chemists' Society, 2004.

BANKS, D. Food-service frying. In: PERKINS, E. G.; ERICKSON, M. D. (Eds.). Deep frying: chemistry, nutrition, and practical applications. Champaign: AOCS Press, 1996. p. 245-257.

BASTIDA, S.; SÁNCHEZ-MUNIZ, F. J. Polar content vs. TAG oligomer content in the frying-life assessment of monounsaturated and polyunsaturated oils used in deep-frying. Journal of the American Oil Chemists' Society, v. 79, n. 5, p. 447-450, 2002.

BELITZ, H. D.; GROSCH, W. Food chemistry. 2nd ed. Berlim: Springer, 1999.

BRASIL. Resolução RDC nº 359, de 23 de dezembro de 2003a. Aprova Regulamento Técnico de Porções de Alimentos Embalados para Fins de Rotulagem Nutricional. Diário Oficial da República Federativa do Brasil, Poder Executivo, Brasília, DF, 26 dez. 2003.

BRASIL. Resolução RDC no 360, de 23 de dezembro de 2003b. Aprova Regulamento Técnico sobre Rotulagem Nutricional de Alimentos Embalados, tornando obrigatória a rotulagem nutricional. Diário Oficial da República Federativa do Brasil, Poder Executivo, Brasília, DF, 26 dez. 2003.

CHOE, E.; MIN, D. B. Chemistry of deep-fat frying oils. Journal of Food Science, v. 72, n. 5, p. R77-R86, 2007. PMid:17995742. http:// dx.doi.org/10.1111/j.1750-3841.2007.00352.x

CODEX ALIMENTARIUS COMMISSION. Standard for named vegetable oils (Codex-stan 210). Rome: FAO/WHO, 2003.

DOBARGANES, M. C.; MÁRQUEZ-RUIZ, G. Regulation of used frying fats and validity of quick tests for discarding the fats. Grasas y Aceites, v. 49, n. 3-4, p. 331-335, 1998. http://dx.doi.org/10.3989/ gya.1998.v49.i3-4.735

DOBARGANES, M. C.; VELASCO, J.; DIEFFENBACHER, A. Determination of polar compounds, polymerized and oxidized triacylglycerols, and diacylglycerols in oils and fats. Pure and Applied Chemistry, v. 72, n. 8, p. 1563-1575, 2000. http://dx.doi. org/10.1351/pac200072081563 
FOOD AND DRUG ADMINISTRATION - FDA. Food Labeling Guidance: guidance for industry - a food labeling guide. FDA, 2009. Disponível em: <http://www. fda.gov/Food/GuidanceComplianceRegulatoryInformation/ GuidanceDocuments/FoodLabelingNutrition/FoodLabelingGuide/ default.htm>. Acesso em: 12 set. 2009.

FIRESTONE, D.; STIER, R. F.; BLUMENTHAL, M. M. Regulation of frying fats and oils. Food Technology, v. 45, n. 2, p. 90-94, 1991.

FRAIS. Fri-check. Disponível em: $<$ http//:www.frais.com.br $>$. Acesso em: 13 out. 2009.

FRITSCH, C. W. Measurements of frying fat deterioration: a brief review. Journal of the American Oil Chemists' Society, p. 272274, 1981.

GERDE, J. et al. Frying performance of no-trans, low-linolenic acid soybean oils. Journal of the American Oil Chemists' Society, v. 84, n. 6, p. 557-563, 2007.

GERTZ, C. Chemical and physical parameters as quality indicators of used frying fats. European Journal of Lipid Science and Technology, v. 102, p. 566-572, 2000. http://dx.doi.org/10.1002/14389312(200009)102:8/9<566::AID-EJLT566>3.0.CO;2-B

HARTMAN, L.; LAGO, R. C. A. Rapid preparation of fatty acid methyl esters from lipids. Laboratory Practices, v. 22, p. 475-476, 1973. PMid:4727126.

HORWITZ, W. Official Methods of Analysis of Association of Official Analytical Chemists. 13th ed. Washington: AOAC, 1980.

HOUHOULA, D. P.; OREOPOULOU, V.; TZIA, C. A kinetic study of oil deterioration during frying and a comparison with heating. Journal of the American Oil Chemists' Society, v. 79, n. 2, p. 133-137, 2002.

INNAWONG, B.; MALLIKARJUNAN, P.; MARCY, J. E. The determination of frying oil quality using a chemosensory system. Lebensmittel-Wissenschaft und -Technologie, v. 37, p. 35-41, 2004.

LIMA, J. R.; GONÇALVES, L. A. G. Parâmetros de avaliação da qualidade de óleo de soja utilizado para fritura. Química Nova, v. 17 , n. 5 , p. $392-396,1994$.

MACHADO, E. R.; GARCÍA, M. C. D.; ABRANTES, S. Alterações dos óleos de palma e de soja em fritura descontínua de batatas. Ciência e Tecnologia de Alimentos, v. 28, n. 4, p. 786-792, 2008. http:// dx.doi.org/10.1590/S0101-20612008000400004

MACHADO, E. R. et al. Uncontrolled variables in frying studies: differences in repeatability between thermoxidation and frying experiments. Grasas y Aceites, v. 58, n. 3, p. 283-288, 2007.

MACHADO, E. R. et al. Quantitative evaluation of monoepoxyacids, monoketoacids and monohydroxyacids in fats and oils used in discontinuous frying of potatoes. Ciência e Tecnologia de
Alimentos, v. 28, n. 3, p. 675-682, 2008. http://dx.doi.org/10.1590/ S0101-20612008000300025

MARMESAT, S. et al. Quality of used frying fats and oils: comparison based on chemical and physical oil properties. International Journal of Food Science and Technology, v. 42, p. 601-608, 2007. http://dx.doi.org/10.1111/j.1365-2621.2006.01284.x

O'BRIEN, R. D. et al. Cottonseed oil. In: SHAHIDI, F. (Ed.). Bailey's industrial oil and fat products. New Jersey: John Wiley, 2005. v. 2.

OSAWA, C. C. Testes rápidos (kits) para avaliação da qualidade de óleos, gorduras e produtos que os contenham e sua correlação com os métodos oficiais da AOCS. 2005. 403 f. Dissertação (Mestrado em Tecnologia de Alimentos)-Faculdade de Engenharia de Alimentos, Universidade Estadual de Campinas, Campinas, 2005.

OSAWA, C. C.; GONÇALVES, L. A. G.; GRIMALDI, R. Nova ferramenta destinada ao monitoramento e à inspeção do descarte "in situ" de óleos e gorduras de fritura. Revista Brasileira de Vigilância Sanitária, v. 1, n. 2, p. 102-107, 2005.

OSAWA, C. C.; GONÇALVES, L. A. G.; RAGAZZI, S. Potentiometric titration applied to free fatty acid determination of edible oils and fats. Química Nova, v. 29, n. 3, p. 593-599, 2006. http://dx.doi. org/10.1590/S0100-40422006000300031

PAUL, S. P.; MITTAL, G. S. Regulating the use of degraded oil/fat in deep-fat/oil food frying. Critical Reviews in Food Science and Nutrition, v. 37, n. 7, p. 635-662, 1997. PMid:9408730. http://dx.doi. org/10.1080/10408399709527793

SAGUY, I. S.; DANA, D. Integrated approach to deep fat frying: engineering, nutrition, health and consumer aspects. Journal of Food Engineering, v. 56, p. 143-152, 2003. http://dx.doi. org/10.1016/S0260-8774(02)00243-1

SHAHIDI, F.; WANASUNDARA, J. P. D. Extraction and analysis of lipids. In: AKOH, C. C.; MIN, D. B. (Eds.). Food lipids: chemistry, nutrition, and biotechnology. New York: Marcel Dekker, 1998.

STEVENSON, S. G.; VAISEY-GENSER, M.; ESKIN, N. A. M. Quality control in the use of deep frying oils. Journal of the Americal Oil Chemists' Society, v. 61, n. 6, p. 1102-1108, 1984.

SUNDRAM, K. Modulation of human lipids and lipoproteins by dietary palm oil and palm olein: a review. Asia Pacific Journal of Clinical Nutrition, n. 6, p. 12-16, 1997.

TESTO. Testo 265. Disponível em: <http://www.testo.com>. Acesso em: 13 oct. 2009.

VISCOFRIT. Cualificadores de aceites de fritura. Disponível em: <http://www.viscofrit.com/>. Acesso em: 18 out. 2006.

WARNER, K.; FEHR, W. Mid-oleic/ultra low linolenic acid soybean oil: a healthful new alternative to hidrogenated oil for frying. Journal of the Americal Oil Chemists' Society, v. 85, p. 945-951, 2008. 